The Geneva Papers on Risk and Insurance, 17 (No. 62, January 1992), 81 -104

\title{
Changing the Retirement Age in Germany
}

\author{
by Winfried Schmähl*
}

Concepts and some Reflections on possible Consequences of the German Pension Reform ${ }^{1}$

\section{Introduction}

In November 1989, the West German Parliament enacted the "1992 Pension Reform Act". ${ }^{2}$ The aim of this act was to reduce future pension expenditure within the statutory pension insurance scheme, and for the "burden" to be shared in a "balanced" manner. Among the major changes and instruments of the act are the pension adjustment procedure (which links pension adjustment rates to the development of average net earnings instead of average gross earnings), and the introduction of a so called "self regulating mechanism": Politically, a target pension level is fixed and the contribution rate becomes a dependent variable. Federal grants, which stem from the general public budget, are linked not only to increases of (average gross) earnings (as today) but also to the development of the contribution rate of the pension scheme.

This reform package also included changes in the conditions for old age pensions claims, especially concerning retirement ages. This latter element of the reform act is the topic of this paper. ${ }^{3}$ The decisions are aimed particularly at postponing the "exit" from working life, and thus at stopping the trend towards earlier retirement. Up to the final political decision, this measure was enormously disputed. But nevertheless it became an element of a broad political consensus between the governing parties and the most important opposition party in the German parliament, and between trade unions and employers' associations. This was

* Head of Department of Economics, Centre for Social Policy Research and Professor, Department of Economics, University of Bremen.

${ }^{1}$ Revised version of a paper presented at the annual conference of the European Society for Population Economics (ESPE) in Pisa, Italy, June 6-8, 1991. Helpful comments made by my research assistant Holger Viebrok are gratefully acknowledged.

2 The reason for this name is that the act should become effective in 1992 .

${ }^{3}$ For a detailed analysis of the discussion concerning the Pension Reform Act and some of its possible effects see Schmähl (1990b), and for integrating these tasks in a broader context Schmähl (1987 and 1990a). 
probably facilitated by the fact that the new regulations will only come into force in about 10 years, and because some people hope or expect that changes will still be possible. ${ }^{4}$ Another important element concerning retirement is the introduction of a partial pension into the statutory pension insurance (phased retirement) which is due to start in 1992.

The statutory pension scheme in West Germany is a compulsory insurance for all employees (except for permanent civil servants). This scheme will also be introduced in 1992 in the new part of the Federal Republic, i.e. in East Germany. The employee and the employer both pay half of the social security contribution on the basis of earnings which is subject to compulsory insurance, up to the contribution ceiling. ${ }^{5}$ However, the statutory pension scheme also covers some of the self-employed, some of them on a compulsory and some on a voluntary basis. Thus, craftsmen (subject to special insurance conditions) have been compulsory members of the statutory pensions schemes since 1939. In 1972, it was made possible for all self-employed to enter the statutory pension scheme on application as compulsory members. ${ }^{6}$

The statutory pension insurance is by far the most important pension scheme in West Germany, because about $80 \%$ of all employees in West Germany are blue and white collar workers. About $30 \%$ of the entire West German "Social Budget" involves expenditures of this scheme. This is nearly three quarters of all expenditure for old age security (not including private life insurance), and about $10 \%$ of net national product (national income) in West Germany.

In the following paper I will first briefly explain the reasons for the mentioned changes concerning retirement ages (2.) and outline different forms of exits from working life (3.). Then the existing rules for retirement age in the statutory pension scheme will be presented (4.), as well as the legislative changes (5.). The West German parliament decided on measures concerning the West German pension scheme under relevant or expected conditions when the decision was prepared and made. Meanwhile, the political and economic situation has changed fundamentally in the process of the German unification. The tasks and problems in connection with this very complex and complicated situation cannot be discussed here. Only some remarks shall be made, pointing out some of the new aspects in introducing the West German pension rules concerning retirement ages in East Germany (6.). The question will be posed as to whether there will be changes, particularly in long term perspective, especially concerning the demographic situation and its development. It is specifically interesting to reflect upon the potential effects that the new legislative regulations concerning retirement will have, which will partly come into force only gradually and after the turn of the century. How will enterprises and employees react to the changes in institutional

\footnotetext{
${ }^{4}$ Some other reasons may have been that the deductions from the "full pension" are relatively small (as will be pointed out later). In addition, for many years the opposition party agreed with the ruling political parties on fundamental objectives and methods of pension policy. If the opposition party had to take over political power it would be forced to decide upon reform measures itself.

5 The contribution ceiling amounts to 1.6 to 1.8 times of the average gross earnings of all insured persons.

6 The organization of the statutory pension scheme, as compulsory insurance for all employees (regardless whether they are employed in the private or in the public sector with the only exception of permanent civil servants), is divided in pension schemes for blue-collar workers, for white-collar workers and for miners.
} 
regulations, and which consequences will this have? Answers to this complex question must remain speculative, because they refer to the future. Comments regarding behavioural responses in Germany have become additionally difficult, because of the fundamental structural changes after German unification, and because the consequences of all the problems and tasks are not visible at present. This is why I will ask, what conditions which are relevant for the reactions on the new rules in the pension scheme could be expected and whether these conditions could be favourable in promoting the aims linked to these new rules.

\section{Reasons for changing "Retirement Ages" in the German Statutory Pension Insurance Scheme}

The academic and political discussion ${ }^{7}$ and the decisions in West Germany's Parliament were directly initiated by demographic structural changes. These changes include the low fertility rate, which is about $2 / 3$ of the value that is necessary for maintaining the number of the population, and the higher life expectancy and its consequences for pension financing. According to assumptions presently considered reliable (constant fertility rate and further slow increase of the life expectancy) for the original part of the Federal Republic (West Germany) and its German population (i.e. without foreigners and without net migration) this would have the consequence that until 2030 the population would decrease by about 14 million people (from 56 million to 42 million). However, the number of people aged 60 or more would increase by 4 million. Thus, the age structure of the population will change considerably. The old age dependency ratio - defined as the ratio of the number of people being 60 years or older to people from age 20 to 60 - would increase from at present $36 \%$ to $81 \%$ in the year 2030 .

The age limits used above for determining the beginning and the end of the working period ( 20 and 60 years of age) largely correspond to the West German situation, being the consequence of longer school and post-school education and above all the tendency of earlier exit from working life. For example within 10 years $(1970-1980)$ the labour force participation rate (LFPR) of 63 years old male employees has decreased from $67 \%$ to $27 \%$ in West Germany (meanwhile - 1989 - LFPR is about $21 \%$ ). This was decisively influenced by the flexible retirement age in the pension schemes that was introduced in 1972. This allows a potential recipient under relatively favourable conditions, to receive a pension at age 63 instead of 65 .

Figure 1 gives information on the development of the LFPR for different male cohorts. It clearly shows the effect of the changes in social security law, even if the reduction of LFPR on the whole also depends on other factors, especially on the worsened situation in the labour market. The interests of employers in rejuvenating their workforce, and the interests of the trade unions in shortening working life, largely corresponded. However, retirement has not always been only a voluntary decision, and sometimes it was expected that the elderly leave their jobs for the younger. The annual working time has also decreased.

Figure 2 gives cross-sectional information for LFPRs of age groups of both sexes for the years 1970, 1980 and 1989. The remarkable reduction of LFPR in the male age groups of 60-64 is obvious, as well as for the 55-59 age group. This has partly been the consequence

\footnotetext{
${ }^{7}$ For a detailed analysis and different standpoints of the (West) German discussion see the articles included in Schmähl (1988) and for an overview Jacobs and Schmähl (1989).
} 


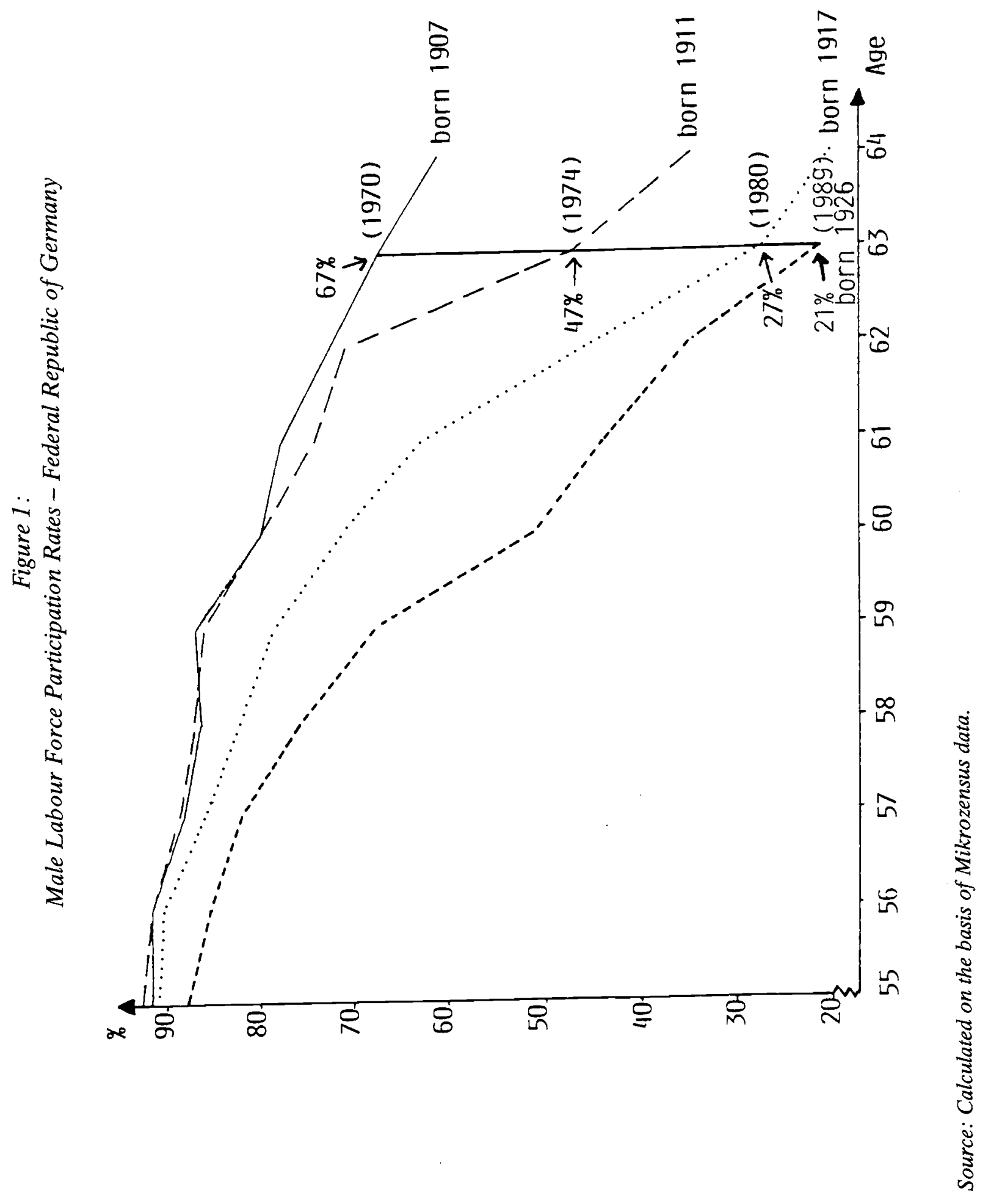



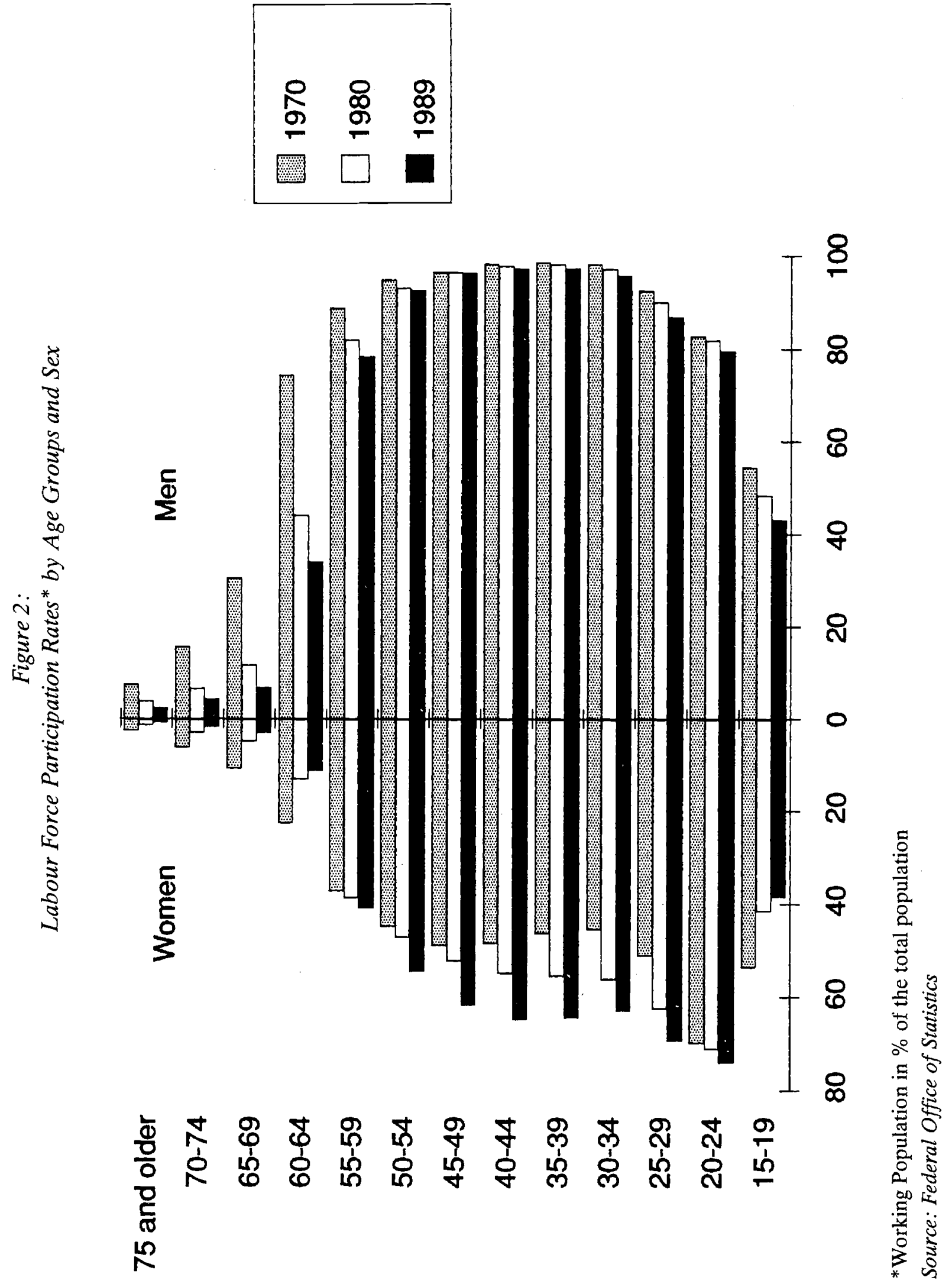
of special pre-retirement possibilities outside the statutory pension scheme. In contrast, the LFPR of women increased for the age groups between 25 and 55, especially due to rising LFPR of married women and an increasing number of single women. ${ }^{8}$

In particular lower retirement ages had serious financial consequences for the pension schemes as is evident by the lower contribution revenue and higher pension expenditure. The financial situation of the pension scheme would ceteris paribus increasingly come under pressure due to the demographic development.

Besides the aforementioned financially motivated interests in changing the retirement age, it was particularly indicated from a gerontological point of view, that for many employees - especially if they are healthy - early retirement is not only a "blessing". It was also pointed out that the experiences and competences of older employees were no longer used, and that in view of the higher life expectancy the non-working period of the life cycle increasingly becomes longer (even now the post-working period is about one quarter of the total length of life). Consequently, later retirement could be justified. From a gerontological point of view, the introduction of partial retirement possibilities were especially emphasized. This has been realized by the pension reform act as well.

The trade unions and the most important German opposition party (the Social Democrats) resisted the raising of the retirement age. They mentioned the high present unemployment rate. It cannot be contested that in times of high unemployment rates the raising of the retirement age results in a shifting of unemployment as more younger people would be affected. However, the new regulations were to be implemented after the turn of the century. The German discussion shows clearly how difficult it is in politics to discuss measures from a long term perspective. Those who argued in favour of changing retirement rules pointed out that in the long term there might be a tightening of the labour market and a shortage of qualified (especially native) workers, because of a demographic induced reduction of labour supply. The political agreement upon changing retirement conditions, however, was easier because the effects of the measures will begin in more than 10 years from the time of decision making. Thus will allow workers and firms to adjust their decisions to the changing legal circumstances, and leave the opportunity to change the political decisions. So, for example, to postpone the starting point of the new regulations is easy, but to implement them very quickly and at an earlier date would cause many conflicts because of the necessary time for adjusting to the new situation.

Among other things, however, it was pointed out that many employees stop working due to invalidity before reaching retirement age. Therefore, postponing retirement ages may to a high degree only cause a shift from old age pensions to invalidity pensions, so that consequently lower pension expenditure could not be expected. life.

This directly leads to the next point, which is the different types of exit from working

\section{Types of exit from working life}

The scenario, that people are employed until eligible for an old age pension of the statutory pension scheme and then stop working totally, is only one of many types of

${ }^{8}$ For a detailed analysis of changing LFPR on pension financing see Schmähl (1989a). 
withdrawal from working life. When an older employee stops working, he/she does not necessarily receive an old age pension, because there are diverse types of (early) withdrawal. The following are particularly important:

- Unemployment of the older employee entitles the receipt of benefits from the unemployment insurance, and afterwards possibly an early old age pension because of previous unemployment.

- Unsatisfactory health conditions, with the consequence of the partial or complete ending of working-life lead to the receipt of an invalidity pension. Partly claiming an invalidity pension can, however, (according to the West German experience) depend on labour market conditions.

- There exist possibilities of receiving benefits from a pre-retirement scheme (often introduced as a measure of labour market policy), in order to avoid unemployment of older employees, or to give incentives so that they quit their jobs earlier and thereby increase the chances for the employment of younger people. In February 1990, a regulation on pre-retirement was introduced in the GDR that has continued to be valid - in a modified form - after German unification for East Germany. It was extended in July 1991, allowing now people to "retire" at age 55 by claiming a special pre-retirement benefit. ${ }^{9}$ In West Germany, there existed a special pre-retirement scheme from 1984 to $1988 .{ }^{10} 11$

These different possibilities for exit from working life are important in regards to the possibility of substituting different types of benefits. This can have the effect of shifting costs between different branches of the social security system (see Casey [1989] for some examples).

Concerning the structure of the retirement conditions, several important differences have to be considered:

- Is the retirement age rigid (fixed) or flexible?

- Is it only possible to receive the full amount of an old age pension (with or without the possibility of being gainfully employed, may be only up to a certain earnings limit) or is it also possible to receive a partial old age pension while still working part-time (and later switching to full retirement and a full old age pension)?

While receiving an old age pension, different activities can be performed. Among them, as mentioned, is either full-time or part-time gainful employment. This will be considerably influenced by the pension amount (respectively the income of the pensioner).

Concerning labour force participation of old age pensioners, there were important differences between the two former German states. In East Germany retirement age was rigid -60 years for women and 65 for men. Labour force participation, even of old age pensioners,

9 This benefit is $65 \%$ of last net earnings and is paid up to the retirement age of the statutory pension scheme (in 1992 this will be in East Germany age 60).

10 This clearly shows that possibilities of early retirement are not primarily introduced as an instrument for humanizing working life, but instead in order to cope with problems of the labour market, especially unemployment (pre-retirement instead of unemployment of younger employees).

11 Before receiving an old age pension, activities in only one's own household (not in the labour market) or activities in the shadow economy (either in the sense of "moonlightening" or e.g. by performing social services) also could have taken place. 
was relatively high. In June 1990 (the month before the introduction of the "economic, currency and social union" between the two German states), $16 \%$ of female pensioners in the age group of 60 to 64 were employed and $6 \%$ in the age group of 65 to 69 . For male pensioners $12 \%$ in the age group 65 to 69 , and $11 \%$ in the age group 70 to 74 , were working with earnings on an average as high or even higher than the pensions people in the above mentioned age groups received on the average. ${ }^{12}$

\section{The existing "retirement ages" and retirement conditions in the German Statutory Pension Insurance Scheme}

At present there exist different retirement ages in the statutory pension insurance scheme. According to different ages and under certain conditions an old age pension can be paid without having health impairments and reduced working capacity (invalidity). Table 1 shows in a simplified manner the conditions for claiming different types of old age pensions.

The retirement age in the statutory pension scheme is presently flexible in view of the different ages, from which an old age pension can be claimed. But, up to the end of 1991, it is not flexible concerning the proportion to which the pension can be claimed: only full retirement is possible. In case of early retirement before age 65 , certain earnings limits exist for working besides receiving an old age pension (earnings test). If these limits are exceeded, no pension is paid. At age 65 or above such restrictions do not exist any longer. In fact, however, the contract concerning the main occupation is normally terminated at the age of retirement. ${ }^{13}$

It should be mentioned that the "retirement earnings test" in the U.S.A. is completely different from the regulation concerning additional income for early retirees in Germany: The earnings test in the U.S.A. is only for working after the "normal" retirement age of 65 years, while in Germany for working before "normal" age of retirement (i.e. 65). In the U.S.A. until 1989, for $\$ 2$ of earnings the pension was reduced by $\$ 1$, while from 1990 on pensions are now reduced by $\$ 1$ for every $\$ 3$ of earnings. In contrast to the U.S.A. in (West) Germany an "all or nothing” principle exists.

The different retirement ages of the West German Scheme will be introduced in East Germany in 1992.

Table 2 shows how many West German pensioners, who received their pension for the first time in 1989, made use of one of the different possibilities. There are remarkable differences with regard to invalidity and old age pensions between blue and white collar workers and between males and females.

12 This information is based on (the first wave of) the socio-economic panel for the former GDR.

13 As mentioned above, there is not much information about employment after the age of 65 for West Germany as compared to East Germany, until the unification. 
Table 1:

Retirement age and qualifying conditions to receive an old age pension in the German Statutory Pension Insurance Scheme

\begin{tabular}{|c|c|c|c|c|}
\hline \multirow[b]{2}{*}{$\begin{array}{l}\text { Minimum } \\
\text { age }\end{array}$} & \multicolumn{2}{|c|}{ Minimum... } & \multirow[b]{2}{*}{$\begin{array}{l}\text { Further } \\
\text { conditions }\end{array}$} & \multirow[b]{2}{*}{$\begin{array}{l}\text { Earnings } \\
\text { limitation } \\
\text { (monthly) }\end{array}$} \\
\hline & $\begin{array}{c}\text { years of } \\
\text { contribution } \\
\text { payments }^{1}\end{array}$ & $\begin{array}{l}\text { so called } \\
\text { "insurance } \\
\text { years" } 2\end{array}$ & & \\
\hline 60 & 15 & 35 & Invalidity & $\begin{array}{l}1 / 7 \text { of the } \\
\text { reference } \\
\text { income }{ }^{3} \\
\text { (age until 62) }\end{array}$ \\
\hline & & & & $\begin{array}{l}\text { DM } 1000 \\
\text { (age of } 62 \\
\text { or more) }\end{array}$ \\
\hline 60 & $\begin{array}{c}15, \\
\text { among them } \geq 8 \\
\text { years of } \\
\text { compulsory } \\
\text { contribution } \\
\text { payments } \\
\text { during } \\
\text { last } 10 \text { years }\end{array}$ & & $\begin{array}{l}52 \text { weeks of } \\
\text { unemployment } \\
\text { during the last } \\
1 \frac{1}{2} \text { years. }\end{array}$ & $\begin{array}{l}1 / 7 \text { of the } \\
\text { reference } \\
\text { income }^{3}\end{array}$ \\
\hline 60 & $\begin{array}{c}15, \\
\text { among them }>10 \\
\text { years of } \\
\text { compulsory } \\
\text { insurance during } \\
\text { last } 20 \text { years }\end{array}$ & & $\begin{array}{l}\text { Entitlement only } \\
\text { for women }\end{array}$ & $\begin{array}{l}1 / 7 \text { of the } \\
\text { reference } \\
\text { income }^{3}\end{array}$ \\
\hline 63 & 15 & 35 & None & DM 1000 \\
\hline 65 & 5 & & None & None \\
\hline
\end{tabular}

${ }^{1}$ Also including periods for example of military service.

${ }^{2}$ Also including periods of education and vocational training, unemployment, temporary disability, and pregnancy.

${ }^{3}$ No earnings test for employment of short duration. The reference income coincides with the average earnings of all compulsory insured persons in the year $t-2$.

$1 / 7$ of the reference income in 1991 is DM 480. 
Table 2:

Frequency Distribution of Pensions

(without pensions for surviving dependants)

in percent

calculated for the first time in 1989 (West Germany)

\begin{tabular}{|l|c|c|c|c|c|}
\hline & \multicolumn{2}{|c|}{$\begin{array}{c}\text { Blue collar } \\
\text { workers }\end{array}$} & \multicolumn{2}{c|}{$\begin{array}{c}\text { White collar } \\
\text { workers }\end{array}$} \\
\hline & Men & Women & Men & Women \\
\hline among all pensions (Sum = 100) & 44,1 & 17,1 & 22,9 & 18,4 \\
\hline Disability pensions & 55,9 & 82,9 & 77,1 & 81,6 \\
\hline Old age pensions & 24,3 & 1,7 & 17,6 & 2,3 \\
\hline among old-age pensions (sum $=100)$ at age .. & & & \\
\hline 60, unemployed & - & 31,0 & & 42,5 \\
\hline 60, women & 18,1 & 0,6 & 17,9 & 1,8 \\
\hline 60, handicapped & 28,3 & 1,1 & 33,7 & 2,3 \\
\hline 63 & 29,3 & 65,5 & 30,4 & 50,5 \\
\hline 65 & 0,1 & 0,1 & 0,4 & 0,2 \\
\hline Postponed, $>65$ & & & & & \\
\hline
\end{tabular}

Source: VDR, Rentenzugangsstatistik 1989

The high percentage of disability (invalidity) pensions for male blue collar workers clearly shows that an increase in the average retirement age can take place, for example, if invalidity pensions before the age of 60 are reduced relatively.

Concerning old age pensions, it can be seen from Table 2 that only about $30 \%$ of male pensioners retire at age 65 , and $70 \%$ between age 60 and 64 . For women, the ratios are quite different.

Table 3 gives some information about the reasons for these differences: Those people who claimed their pension at the age of 65 , who did not meet the requirements for other old age 
pensions, had in particular only a relatively small number of years of insurance. Often they also had relatively low wages during their working life, and, therefore, sometimes could not afford to stop employment earlier. ${ }^{14}$

In order to understand the changes, and their possible consequences, which are initiated by the "1992 Pension Reform Act" (decided upon in late 1989), it is important to take into consideration the "pension formula", because this formula is decisive for the effects on the individual pension when retiring at different ages.

Table 3:

Average amount of old-age pensions (in DM) and average number of years of insurance in the statutory pension insurance scheme (in years) on July $1^{\text {st }}, 1989$ (West Germany)

\begin{tabular}{|c|c|c|c|c|c|c|c|c|}
\hline & \multicolumn{4}{|c|}{ Men } & \multicolumn{3}{c|}{ Women } \\
\hline & \multicolumn{2}{|c|}{$\begin{array}{c}\text { Blue collar } \\
\text { workers }\end{array}$} & \multicolumn{2}{|c|}{$\begin{array}{c}\text { White collar } \\
\text { workers }\end{array}$} & \multicolumn{2}{c|}{$\begin{array}{c}\text { Blue collar } \\
\text { workers }\end{array}$} & $\begin{array}{c}\text { White collar } \\
\text { workers }\end{array}$ \\
\hline $\begin{array}{c}\text { Kind of old-age } \\
\text { pension }\end{array}$ & DM $^{1}$ & Years & DM $^{1}$ & Years & DM 1 & Years & DM ${ }^{1}$ & Years \\
\hline $\begin{array}{c}\text { 60 years, } \\
\text { unemployed }\end{array}$ & 1788 & 41,9 & 2230 & 42,4 & 745 & 28,8 & 942 & 29,6 \\
\hline $\begin{array}{c}60 \text { years, } \\
\text { women }\end{array}$ & - & - & - & - & 845 & 31,3 & 1235 & 33,9 \\
\hline $\begin{array}{c}60 \text { years, } \\
\text { disabled }\end{array}$ & 1828 & 43,5 & 2176 & 43,5 & 1065 & 38,4 & 1528 & 40,1 \\
\hline 63 years & 1843 & 44,4 & 2346 & 44,8 & 857 & 37,8 & 1359 & 39,0 \\
\hline 65 years & 1159 & 31,4 & 1717 & 32,2 & 401 & 18,5 & 656 & 21,1 \\
\hline Postponed & 1125 & 28,2 & 1883 & 34,1 & 551 & 22,0 & 890 & 24,8 \\
\hline
\end{tabular}

1 rounded

Source: "Rentenanpassungsbericht 1990"

For calculating the initial old age pension (up to the age of 65) the following formula is relevant: The amount of the individual pension $(P I)$ is the product of the following 4 factors:

$$
P I(t)=n \cdot\left(\sum_{t=1}^{n e} \frac{W I(t)}{W A(t) \cdot n e}\right) \cdot s \cdot F(t)
$$

${ }^{14}$ However, this also depends on household income. 


\begin{tabular}{|c|c|c|}
\hline$P I(t)$ & $=$ & individual pension in year $t$ \\
\hline$n$ & $=$ & $\begin{array}{l}\text { number of years of insurance, consisting of years with earnings }(n e) \text { and } \\
\text { other years (e.g. unemployment, education, sickness, childcare) })^{15}\end{array}$ \\
\hline$W I$ & $=$ & individual gross earnings \\
\hline$W A$ & $=$ & average gross earnings of all wage and salary \\
\hline$W I / W A$ & $=$ & $\begin{array}{l}\text { individual average earnings position during covered employment }(=\text { per- } \\
\text { centage of the "individual earnings base") }\end{array}$ \\
\hline 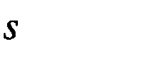 & $=$ & a constant factor of 0.015 for old age pensions \\
\hline$F$ & $=$ & $\begin{array}{l}\text { "general earnings base" }=\text { absolute yearly amount in German marks. - } \\
F(t) \text { was for example in } 1989 \text { about } 0.75 W A(t) .\end{array}$ \\
\hline
\end{tabular}

The first two factors are individual ones, the last two are identical for all (old age) pensioners.

In connection with the "1992 pension reform" there will be some new expressions for the four central elements of the pension formula without changing its contents: The two individual factors will be put together in defining the so called "earnings points" (EP). For example, if individual earnings for one year are equal to average earnings in the same year, the result is $1 \mathrm{EP}$. The second factor of the pension formula will be the "actual pension amount" (APA), i.e. the (monthly) payment in a certain year for $1 \mathrm{EP}$. So the pension formula from 1992 on will read as follows:

$$
P(t)=\Sigma E P \cdot A P A(t)
$$

where $P$ is the pension payment per month.

If the pension is claimed after the age of 65 , according to the present law, an additional $0.6 \%$ per month will be paid (up to the maximum age of 67 ), based on the pension one is able to get at the age 65 .

It is obvious from equation (1), that ceteris paribus retirement before age 65 only has financial consequences for the pensioner in so far that a smaller number of insurance years decreases the pension, whereas the longer phases of receiving pension payments have no consequence for the individual pensioner. ${ }^{16}$ Thus, the reduction of the pension is lower than it would be if an actuarial fair calculation would be used.

\section{Changing "retirement ages" by the "1992 Pension Reform Act"}

Flexible retirement, here the possibility to stop working at different ages in order to get an old age pension, will also exist in the future. Early retirement, however, will become more expensive for the retiree. In addition, a new type of flexibility will be introduced by the possibility of receiving a partial pension.

\subsection{Increasing the retirement age}

The currently existing differences in retirement ages for males and females will be eliminated step by step, starting in 2001 . At the final stage, the earliest possibility to claim an old

15 When including these phases as time of coverage, several conditions and restrictions often exist.

${ }^{16} \mathrm{~A}$ related issue is, whether earlier retirement in fact often results in a longer period of receiving a pension, especially if the retirement is the result of health impairments. For example life expectancy of West German disabled pensioners at, for example, 65 years of age is three years shorter for men and 2,3 years shorter for women, as compared to old age pensioners. These findings are from social security earnings records. See Rehfeld and Scheitl (1991). 
age pension will be at age 62 . Females, therefore, will only receive an old age pension 2 years later than they do at present, while males will be able to receive an old age pension one year earlier than currently (if one neglects the old age pension because of unemployment). ${ }^{17}$

There will, however, be a reduction for those people who retire before the age of 65 , which is the "normal retirement age". This reduction will be introduced step by step, beginning in the year 2001. The following will first describe the general approach, and then the transition period for gradually increasing the "reference retirement age" up to the age of 65 .

The reductions will make early retirement more expensive for those who will leave the workforce before the "reference retirement age", i. e. at the end of the transition period age 65 . In comparison to the present law, reductions before age 65 , as well as additions to the pension after age 65 , will be changed. Technically this will be done by introducing an additional factor into the pension formula. This so called "entrance factor" (EF) will be 1 at every "reference retirement age". This means that after the transition period EF will be 1 at age 65 . In case of earlier retirement, the pension will be reduced for every month by $0.3 \%(0.003)$, for a maximum of 36 month, thus maximal:

$$
1-(36 \cdot 0.003)=1-0.108=0.892 \text {. }
$$

In case of postponing the retirement beyond age 65 , the pension will be increased by $0.5 \%(0.005)$ per month. The possibility to postpone the pension will be unlimited; at present postponing a pension is only possible for two years. While the reductions will be introduced after the year 2001, the new conditions for postponing receipt of a pension will be introduced in 1992. Figure 3 summarizes the effects on the pension.

Figure 3:

Changing the pension claim (100\%) by earlier or later retirement 1$)$

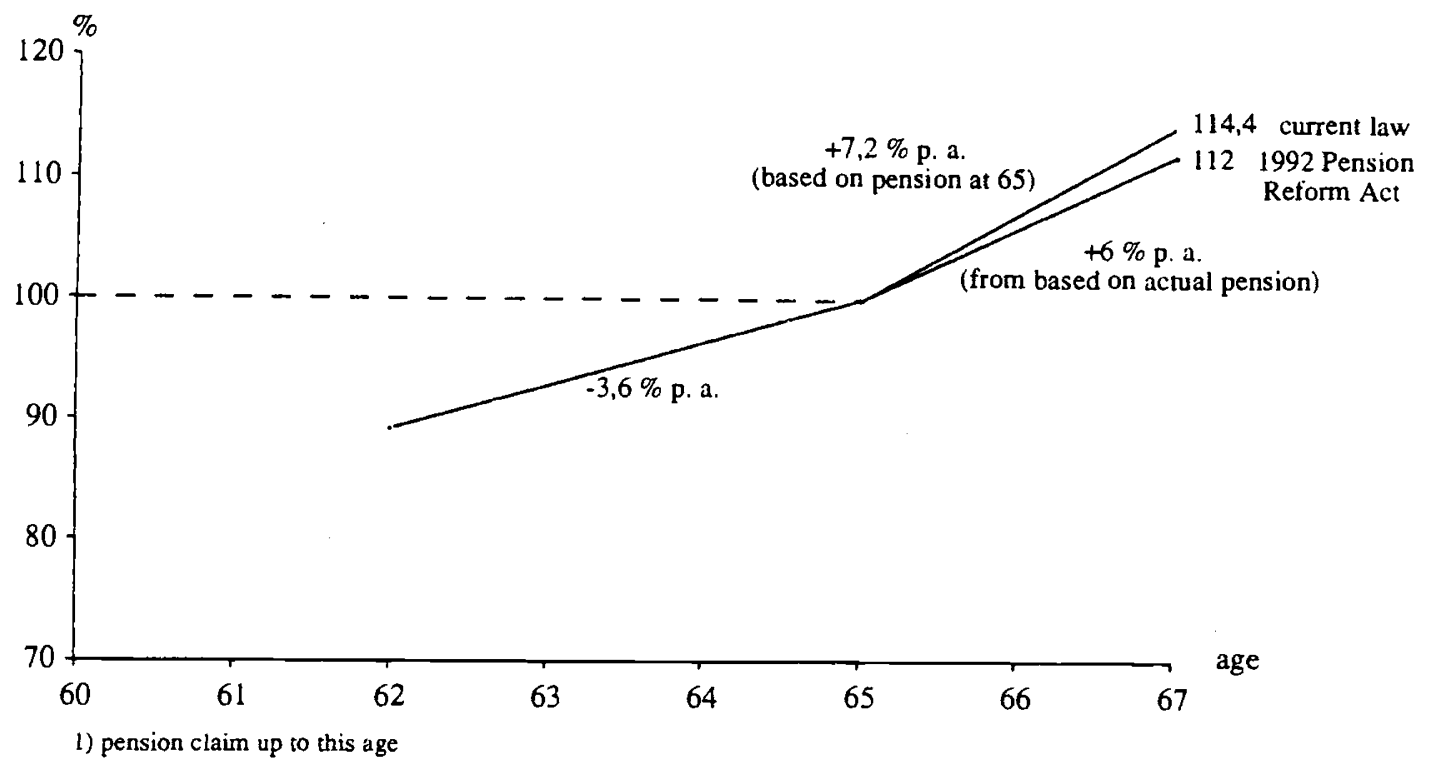

${ }^{17}$ The possibility to obtain an invalidity pension at an earlier age will continue to be unchanged for everybody. The same applies to retirement at age 60 for seriously handicapped persons and for miners who worked for extended periods underground. 
Reductions of $3.6 \%$ per year, in case of earlier retirement, are below the rate of an actuarial fair calculation, and in my view are a distributional motivated compromise. Additional payments in the case of postponing retirement above the age of 65 by $6 \%$ per year (with regard to the pension claim at retirement, not as currently the claim at the age of 65) will be in my view too low for giving remarkable incentives to postpone retirement.

In the U.S.A., there is at present a reduction in the pension of $6.66 \%$ per year between the ages of 62 (earliest possibility) and 65 (normal retirement age). Thus, retiring 3 years earlier a reduction of about $20 \%$ occurs which is nearly twice as high as the one decided upon in Germany.

Like the 1983 amendments to the social security bill in the U.S.A., there are also relatively long transition periods in Germany for introducing reductions respectively for increasing the "reference retirement age" to the age of 65 . In the U.S.A., however, the "normal retirement age" will be increased from 65 to 67 while demographic ageing is far less than in Germany. In the U.S.A. the process of raising the retirement age will start in the year 2003 and will be finished in the year 2015. The increase of earlier retirement ages in Germany from the year 2001 onwards will only be completed by the year 2012, and for some cohorts only in 2017 (see figure 4).

Figure 4 shows the time path of how the earlier retirement ages (60 and 63) will be raised to the age of 65 . It is also demonstrated which cohorts will be affected by the new regulations, when they will be affected, and to what extent. Specifically the degree of pension reduction is displayed in the case of an early exit from employment.

For example, males born in 1941, who will become 63 in the year 2004, can retire without reductions in the year 2005 at age 64 , thus after an additional year of employment. If they want to retire at 63 , they have to accept a reduction for one year (i. e. 3.6\%). For those who were born in 1943 and want to retire at age 63 (in 2006), there already exists a reduction for two complete years. By analogy, one can see in figure 4 how much the "reference retirement age" (i.e. the retirement age without reduction) will rise for those who could retire up to now at age 60 without reductions. ${ }^{18}$

\subsection{Introducing a partial pension (phased retirement)}

From 1992 on, insured employees are entitled to receive a partial pension from statutory pension insurance. This pension can be combined with earnings from gainful employment up to certain new and special earnings limits. There will be three different possibilities for a partial pension. Either one-third, one-half, or two-thirds of the full pension claim will be possible. Partial early retirement will also be an option, after the year 2001, however, with deductions.

The earnings limit, in case of partial retirement (ELP), is dependent on relative individual earnings in the year before retirement $(E P(t-1))$, a factor depending on the type of partial pension (a "multiplier", M) and on the "actual pension amount" (APA).

18 From 1992 on, a new "earnings-test" will also be introduced. Instead of the different conditions shown in Table 1, a uniform earnings limit (EL) will be introduced in case of full retirement before age 65. This will be $1 / 7$ of $W A(t-2)$. 
Figure 4:

Gradual increase of age limits for pre-retirement

in the statutory pension insurance

"full" pension at the age of ...

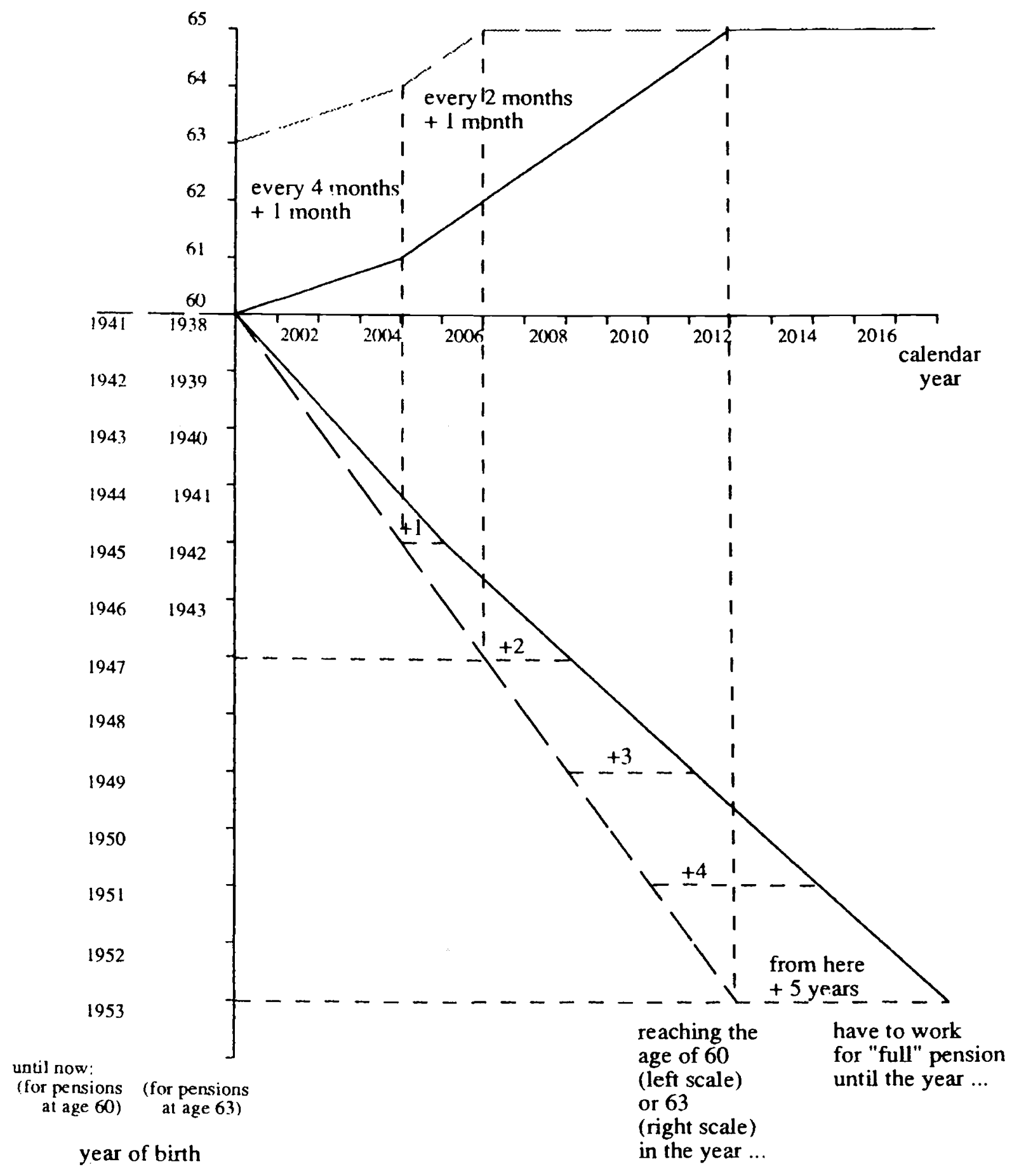


For partial pension of...

$1 / 3$

$1 / 2$

$2 / 3$ the "multiplier" (M) is...

70

52.5

35

So the earnings limit (ELP) is determined for the individual partial pensioner by

$$
E L P(t)=M \cdot E P(t-1) \cdot A P A(t) \text {. }
$$

For example, for $E P(t-1)=1$ (average earner), with $39.58 \mathrm{DM}$ for APA (effective in 1992), and a partial pension of $1 / 3$

ELP is $70 \cdot 1 \cdot 39.58 \mathrm{DM}=2770.60 \mathrm{DM}$ (per month), i. e. earnings up to this amount are allowed.

For a "standard pensioner" (here: 45 years of insurance and being an average earner), i.e. with $45 \mathrm{EP}$, the full pension would have been about $45(\mathrm{EP}) \cdot 39.58 \mathrm{DM}(\mathrm{APA})=1781$ DM. The partial pension (1/3) therefore is $593.70 \mathrm{DM}$. In addition it is possible for this partial pensioner to earn up to $2770.60 \mathrm{DM}$ per month (ELP) without reducing his partial pension.

APA will be adjusted yearly according to the growth rate of average net earnings of all covered employees. Therefore, ELP is also a dynamic variable.

Partial pensioners can shift to another type of partial pension, or to full pension at any time they choose, but must then consider the relevant earnings limit.

Since the employee and the employer must still contribute during the period of receiving a partial pension from earnings, the future entire pension amount will be increased. It is also possible to receive only the partial pension even after the age of 65 . Then for the part of the full pension not claimed the above mentioned additions will be paid.

\section{Retirement ages after the German unification}

When the West German parliament made its final decision on the "1992 Pension Reform Act" on November 9, 1989, it was not imaginable that during the evening of that very day, the East German government would open the border between the two German post-war states. In this paper, I concentrate on only some of the aspects, closely related to retirement ages, whether short-term or long-term, which are a result of this new situation. ${ }^{19}$

The unemployment rate in East Germany, which is no longer hidden as it formerly was, is high and currently rising. One instrument for coping with the labour market problems was, and still is, the introduction and extension of a pre-retirement scheme which is outside the statutory pension insurance scheme. Since February 1990 employees aged 55 for women and 57 for men could receive pre-retirement benefits, which are actually payed by the unemployment insurance. Since July 1991 pre-retirement at age 55 is also possible for men. Benefits are now $65 \%$ of individual last net earnings. ${ }^{20}$ Older cohorts are now faced

19 For detailed analysis of the problems of integrating the fundamentally different pension schemes in West and East Germany see Schmähl (1990c) and Schmähl (1991).

${ }^{20}$ The individual "reference income" for calculating pre-retirement benefits will increase in accordance with average net earnings development. The time of being a pre-retiree is counted for calculating old age pensions of the statutory pension insurance scheme. 
with the unexpected situation of no longer being needful on the labour market - for men 10 years before the retirement age in East Germany (which is up to the end of 1991 still 65 for men).

In 1992 the West German statutory pension insurance scheme shall in principle also become effective in East Germany. ${ }^{21}$ Then invalidity pensions, as well as the flexible retirement age (instead of a fixed retirement age of 60 for women and 65 for men), will be introduced in accordance with the West German rules. This will, in combination with the unfavourable labour market conditions, remarkably increase the number of pensioners. Government estimates are relatively cautious in expecting an additional 350.000 pensioners in 1992 (150.000 invalidity pensioners and 200.000 old age pensioners). That will be an increase in the number of East German pensioners by $12.2 \%$ ( $7.8 \%$ of old age pensioners and $50 \%$ of invalidity pensioners). The average retirement age in East Germany will, therefore, be reduced and pension expenditure increased. The necessary additional revenue for financing these and other additional expenditures will, to a large degree, come from contribution revenue from West Germany. This is because in 1992 deficits of the pension scheme in East Germany will no longer be financed out of the federal budget as will be the case from July 1990 to the end of 1991.

Concerning development in the long run, the influence of German unification on demographic factors, besides economic development, is especially interesting in this context. Because of the higher fertility rate and the lower life expectancy in East Germany, the age structure in East Germany is a bit more "favourable" concerning financing of old age pensions than in West Germany. For example average life expectancy of a new born child is now 71.8 years for males in the West, 69.5 years in the East, respectively 78.4 years for females in the West instead of 75.5 years in the East. Even at age 60, life expectancy between West and East Germany differs remarkably: for women 21.7 years in the West and 19.2 in the East, for men 17.3 years (West) and 15 years (East).

However, many researchers expect a relatively rapid convergence concerning fertility rates as well as labour force participation rates for women (that are now higher in the East), while it can be supposed that mortality rates will not converge as quickly. Taking into account that East Germany's population is only about $1 / 5$ of the total German population, the structural demographic conditions will not be changed fundamentally, because of the German unification. Germany will remain an ageing society, and the overall trend in ageing will not be changed. Therefore, until now there is in my view no reason to change the political decisions of the "1992 Pension Reform Act" concerning retirement ages. In addition, lowering retirement ages, or postponing the date, when the conditions concerning retirement ages shall become effective, can be introduced very rapidly. But an increase in retirement ages makes it necessary to decide early, some time before the new rules become effective, in order to allow employees as well as employers to adapt their planning to the new conditions.

\section{Some remarks on possible effects in the future}

"What will be the effect of changing the legal conditions for receiving a retirement pension, especially concerning the average retirement age?" This is a very complex question

21 There are, however, several transitional rules which are necessary, particularly because of the different economic conditions in East and West Germany. 
which depends on many often interrelated influencing factors. Some research has been done in the past in Germany concerning early retirement; however, up to this point, nearly nothing has resulted from research regarding the possible effects of measures aimed at changing the trend of retirement age into a development of extending the phase of employment during life cycle.

Above all the effects of the new measures on labour market - especially labour supply, labour market chances for older workers (as a consequence of employer's reactions), - on the financial situation of the pension scheme, and the different dimensions of income distribution are interesting. Concerning the labour market, effects are particularly noteworthy in regard to labour supply and labour market opportunities for older workers, which are partially a consequence of employers' reactions to changing circumstances.

It is especially the questions concerning reactions on the labour market which clearly show that the effects of an institutional change concerning retirement age depend to a large extent on the reactions (decisions) of employees and enterprises which especially depend on expectations of the future development.

Answers at this point, at least concerning Germany, can only be given using very restrictive assumptions. They are, to a large extent, more or less speculations. One can, however, point out some of the conditions that would be favourable for realising the political objectives.

Concerning the financial situation of the pension insurance scheme, some elementary conclusions are obvious: introducing some reductions when retiring before the "normal age of retirement" shifts some of the costs of early retirement to the employee (the pensioner) claiming the pension. These costs are now born from the whole group of contributors and in part from all tax payers via federal grant. This reduces expenditures of the pension scheme, even if retirement age remains unchanged, by reducing ceteris paribus the average pension level. ${ }^{22}$.

If the average retirement age is increased, then the "pensioner ratio" is reduced (i.e. the ratio of the number of pensioners to the number of contributors). The number of pensioners ceteris paribus becomes smaller. Even if there are no additional contributors, the pensioner ratio is lower - that is if older workers stay longer in the labour force and the number of employees does not increase, because this reduces chances of younger employees on the labour market. If, however, a longer working life of the elderly increases the number of contributors (because there is demand for additional labour), the pensioner ratio is reduced to a greater extent.

For the statutory pension insurance in West Germany, there are calculations on how much the necessary contribution rate must be for balancing the budget and how much it will be reduced if the average retirement age is increased by one year. The results show that the contribution rate for example in the year 2030 could be lower between 1.5 to 3 percentage points per year of a higher average retirement age, depending on assumptions concerning other measures influencing pension expenditure development in the future, and on the development of the number of contributors while increasing retirement age.

22 I do not discuss here differences between a cross-sectional and a longitudinal analysis concerning effect of the pension scheme on the financial situation. 
However, the decisive factor will be, how employees and employers decide upon the age of retirement, and on full or partial retirement. ${ }^{23}$

For a comprehensive analysis on the micro level one has to distinguish between employed and unemployed persons. Here, I discuss only decisions of employees. For the individual decision of the employee (concerning labour supply by deciding upon time and type of retirement) the following factors among others will be important:

- The general labour market situation and how it influences for example the risk of becoming unemployed or having the chance to earn additional money while being retired.

- In connection with the formerly stated factor, if the employee is able to continue to work in the former job. This is especially important for gradual retirement, when the employee changes from full-time to part-time employment. Related factors include if the employee still feels able to meet the demands of the workplace made on him, depending among other factors on the characteristics of the job, technological development and changing working conditions.

- A decisive factor is the individual health status. ${ }^{24}$

Moreover, generally important factors are as follows:

- the preference for work and leisure, and relatedly

- the family situation. For example, does the spouse still work and can he/she also retire? If equal retirement ages for men and women exist, as shall be the case in Germany, then the conditions for a joint decision of married couples are changed as compared to the now existing different retirement ages. The individual decision will also take into account a difference in age between the spouses (as often exists). ${ }^{25}$ The joint decision therefore can become more complicated in the future, also because the labour force participation rate of married women in Germany has increased and is still increasing.

Above all it is important to know:

- which consequences retirement has on individual and household income of the employee. Different aspects are relevant:

- the total income replacement rate (i. e. income after retirement compared to income before retirement, including taxation of earnings and pensions as well as other transfer payments),

- the future development of this income depending on its components and their adjustment to general income and price increases (indexing of different types of income can

${ }^{23}$ For some experiences on phased retirement, see Petersen (1989) for Denmark, Kruse and Söderström (1989) for Sweden, Sundberg (1989) for Finland, and additional references which are given there. For the U.S.A. see Reimers and Honig (1989), Quinn et al. (1990). Comparisons are made for example in Schmähl (1989b, Introduction) and Delsen (1990).

24 This (in connection with job requirements) is important for claiming a disability pension as well as retirement pensions at different ages, if there is flexible retirement. For some empirical information see for example Chirikos and Nestel (1991), Holmes et al. (1991). (1989).

25 Concerning the retirement decision of married women in the U.S.A.; see Pozzebon and Mitchell 
be rather different, as is very clearly demonstrated for example by the indexation of statutory pensions (linked to earnings) and occupational pensions (linked to a price index) in Germany. ${ }^{26}$

Relative income, however, is not the only decisive factor, but also the absolute income level which is important in meeting needs or preferences.

Concerning occupational pensions besides the amount of the pension payment it is also important, whether they can be claimed at the same age as the social insurance pensions as it is for the most part at present in Germany ${ }^{27}$ and whether there exist incentives in firm's pension plans to retire at certain ages, as is pointed out for the U.S.A. ${ }^{28}$

The employee, when deciding whether and in which way to retire, has to take into account existing alternatives for receiving an income with or without working. Therefore, for the employee the possibility, the ability and the willingness of being employed, as well as the consequences of working or not working (especially as related to income) will be of central importance.

Keeping these factors in mind, the conclusions which can be made from simple models of household decision making, which are based on given preferences for leisure and work, a budget constraint and relative prices, obviously can only be at first a starting point when looking for possible reactions of the employees on changing retirement conditions.$^{29}$ If it is more costly for the employee to retire early, based on the assumption of a "normal reaction" of individual labour supply, one can conclude (in a more or less isolated manner) that there will be some incentives (as compared to the present situation) to retire later. ${ }^{30}$

Concerning the future development of the health status of employees, there exist quite different assumptions concerning the connection of mortality and morbidity, namely whether a longer life will be accompanied later by invalidity, severe sickness, etc. (Fries [1985]), or whether this will start even earlier and the time span of invalidity, etc. will become longer (Verbrugge [1984]). This, as well as the success in preventing invalidity and the effects of rehabilitation, can have a considerable impact on average retirement age.

The decisions of the firms on labour demand, especially in respect to the employment of older workers, will also depend on various factors. Some of these factors include the expectations of the demand for goods, the development of technical progress, the relative factor costs, as well as the expected development of labour supply. This latter factor, defined in terms of volume and structure, is influenced by demographic development amongst

${ }^{26}$ One could speak here of a "dynamic replacement rate".

${ }^{27}$ See Japan for a quite different situation.

${ }^{28}$ For example in several papers by Kotlikoff and Wise $(1987,1989)$.

${ }^{29}$ For an overview see Burtless and Moffitt (1984).

${ }^{30}$ Looking at the existing additions for deferred pensions, however, currently only $0.1 \%$ of male old age pensioners, and a negligible small number of women have postponed the time of retirement beyond age 65 . Incentives for delayed pension will not be increased as compared to the present situation. Therefore, there is ceteris paribus no reason for optimistic expectations concerning the effect of this special measure. 
other factors. ${ }^{31}$ Firms will compare the costs of employing older workers and their respective productivity. However, very often there are more or less only some vague ideas or assumptions about productivity or the development of productivity over the life cycle. Whether age-earnings profiles (which are important for age-specific labour costs) will change if it becomes "normal" to work longer, is an open question. It is, however, very important how productivity over the life cycle is influenced by technical progress. It is often assumed that the productivity of older workers will decrease. In my view this is disputable. It depends, among other factors, ${ }^{32}$ very much on how much retraining is offered by firms to older workers, and how much they are able and willing to be involved in retraining. These retraining opportunities will be offered by firms, especially if there is an expected lack of qualified manpower. Willingness to invest more in human capital of older workers will increase if the time span for further employment of these people becomes longer.

In addition, the tendency of having more production in the service industry may change the demand for the abilities and qualifications of elderly employees. Less physically demanding jobs and more activities, where experience is useful, can be expected in the future. This, as well as "social competence" of older workers, may be more interesting in the future for the firms (Staehle [1989]). Looking at the structure of qualifications over the life cycle, there is a change from physical ability to more experience, etc. There is some analogy in the research on intelligence carried out by biologists and psychologists concerning "fluid" and "crystallized" intelligence, where the latter increases with age. Crystallized intelligence includes"... the ability to synthesize, social intelligence, cultural knowledge..." (Baltes [1987], p. 614). ${ }^{33}$ Increasing importance of experience may be disputed by the argument that rapid technical progress depreciates experience. However, the necessity of retraining, as mentioned above, has to be stressed.

If firms expect a shortage of qualified (native) manpower, then there can be expected more interest in creating age-adequate job opportunities for the elderly, in particular parttime jobs. They are currently quite unusual for older male workers in Germany. The introduction of a partial pension in the German statutory pension scheme may have the effect of making part-time employment of the elderly a bit more "popular and normal". ${ }^{34}$ These remarks are concentrated on private firms. In the process of changing retirement ages in Germany, however, the role of public employers should not be neglected.

31 Firms also have to take into consideration the different restrictions, especially for dismissing older workers, collective agreement, etc.

32 Reday-Mulvey (1990), pp. 106-107, summarizes some findings, pointing out for example “... that the relationship between age and productivity at work depended above all on the type of tasks undertaken".

33 It is important to look upon all these aspects (a) from a life-span perspective and (b) by taking into account (possible) cohort-specific differences, so for example the degree of "plasticity" of the elderly (for this concept in psychology and physiology see Lerner [1984]).

34 Part-time employment can often be favourable for the firms: "As employers have become more familiar with part-time work, the advantages have increasingly been seen to outweigh possible disadvantages... Experience seems to have been very convincing: almost all part-time work systems have been expanded and made more flexible over time" (Thurman and Trah [1990]), p. 25. 
I would therefore like to conclude that the labour market chances of the elderly are not at all gloomy for the future, especially after the turn of the century, when in Germany "new retirement ages" become effective. ${ }^{35}$

Germany is involved in the process of European integration within the European Communities. There are tendencies in the EC to equalize the retirement ages for men and women, not only in statutory pension schemes, but also in occupational pension schemes. Maybe, Germany will be forced by the European authorities to equalize retirement ages for men and women more quickly than was indicated in the "1992 Pension Reform Act".

To mention one last aspect, many risks exist concerning future political and economic development, in particular concerning the labour market, in particular with respect to migration. The future development of Central and Eastern Europe cannot be foreseen, above all concerning free movement as well as the development of living conditions in these regions. The unexpected developments that made it possible to unify Germany within less than a year after the tumbling down of the inner-German border, makes one very cautious in making firm conclusions about future developments.

Nevertheless, many topics and questions within many disciplines exist for future research. It is thereby, that our knowledge can be increased on the possible consequences of political decisions coping with the complex problems of ageing societies.

35 Concerning the present situation in the U.S.A. Schulz (1990, p. 57) concludes: "A closer look at the shifts taking place in our economy indicates that older workers can indeed be matched with appropriate jobs. The problems lie not so much in the nature of the jobs and their skill requirements but in the attitudes of both older workers and their potential employers, in the rigid structure of the work place, in current hiring practices, in the prevailing wage structure and compensation policies, and in the attitudes toward training older workers." 


\section{REFERENCES}

BURTLESS, G. and MOFFIT, R. A. (1984), The Effect of Social Security Benefits on the Labour Supply of the Aged. In: Aaron; Burtless (Eds.), Retirement and Economic Behavior, Washington, pp. 135-174.

CASEY, B. (1989), Early Retirement: The Problems of "Instrument Substitution" and "Cost Shifting" and Their Implications for Restructuring the Process of Retirement. In: Schmähl (1989b), pp. 133-150.

DELSEN, L. (1990), Part-Time Early Retirement in Europe, in: The Geneva Papers on Risk and Insurance, No. 55, pp. 139-157.

FRIES, J. F. (1985), The Compression of Morbidity. In: World Health Forum; Vol. 6, pp. 47-51.

HOLMES, Ph., LYNCH, M. and MOLHO, I. (1991), An Econometric Analysis of the Growth in the Numbers Claiming Invalidity Benefit: An Overview, in: Journal of Social Policy, Vol. 20, pp. 87-105.

JACOBS, K. and SCHMÄHL, W. (1989), The Process of Retirement in Germany: Trends, Public Discussion and Options for its Redefinition. In: Schmähl (1989b), pp. 13-38.

KOTLIKOFF, L. J. and WISE, D. A. (1987), The incentive effects of private pension plans, in: Z. Bodie et al. (Eds.), Issues in pension economics, Chicago, pp. 283-339.

KOTLIKOFF, L. J. and WISE, D. A. (1989), Employee retirement and a firm's pension plan, in: D. Wise (Ed.), The economics of aging, Chicago, pp. 279-330.

KRUSE, A. and SÖDERSTRÖM, L. (1989), Early Retirement in Sweden. In: Schmähl (1989b), pp. 39-61.

LERNER, R. (1984), On the Nature of Human Plasticity, Cambridge, Mass.

MITCHELL, O. and FIELDS, G. (1985), Rewards for Continued Work: The Economic Incentive for Postponing Retirement. In: David, M.; Smeeding, T. (Eds.), Horizontal equity, uncertainty, and economic well-being, NBER Studies in Income and Wealth Series, Vol. 50, Chicago, pp. 269-286.

PETERSEN, J. (1989b), The Process of Retirement in Denmark: Trend, Public Discussion and Institutional Framework. In: Schmähl (1989), pp. 63-81.

POZZEBON, S. and MITCHELL, O. S. (1989), Married Women's Retirement Behavior. In: Journal of Population Economics, Vol. 2, No. 1, pp. 39-53.

QUINN, J. F., BURKHAUSER, R. V. and MYERS, D. A. (1990), Passing the Torch - The Influence of Economic Incentives on Work and Retirement. Kalamazzo, Michigan.

REDAY-MULVEY, G. (1990), Work and Retirement: Future Prospects for the Baby-Boom Generation, in: The Geneva Papers on Risk and Insurance, No. 55, pp. 100-113.

REHFELD, U. and SCHEITL, O. (1991), Sterblichkeit und fernere Lebenserwartung von Rentnern der gesetzlichen Rentenversicherung - aktuelle Ergebnisse für 1986/1988 und Bilanz zum bisherigen Untersuchungsstand. In: Deutsche Rentenversicherung (DRV), pp. 289-320.

REIMERS, C. and HONIG, M. (1989), The Retirement Process in the United States: Mobility Among Full-Time Work, Partial Retirement, and Full Retirement. In: Schmähl (1989), pp. 115131.

SCHMÄHL, W. (1987), Social policies for reducing demographically induced costs in social security. In: European Journal of Population, Vol. 3, pp. 439-457.

SCHMÄHL, W. (Ed.) (1988), Verkürzung oder Verlängerung der Erwerbsphase? Zur Gestaltung des Übergangs vom Erwerbsleben in den Ruhestand in der Bundesrepublik Deutschland / A shorter or a longer working life? On structuring the transition from work to retirement in the Federal Republic of Germany; in German only, Tübingen (Mohr). 
SCHMÄHL, W. (1989a), Labour Force Participation and Social Pension Systems. In: Johnson, Paul et al. (Eds.), Workers Versus Pensioners: Intergenerational Justice in an Ageing World. Manchester and New York, pp. 137-161.

SCHMÄHL, W. (Ed.) (1989b), Redefining the process of retirement. An international perspective. Berlin and Heidelberg (Springer Publisher).

SCHMÄHL, W. (1990a), Demographic change and social security - some elements of a complex relationship. In : Journal of Population Economics, Vol. 3/1990, pp. 159-177.

SCHMÄHL, W. (1990b), Reformen der Rentenversicherung: Gründe, Strategien and Wirkungen Das Beispiel der "Rentenreform 1992" - Pension Reform: Reasons, Strategies and Effects, in German only, in: B. Gahlen et al. (Eds.), Theorie und Politik der Sozialversicherung, Tübingen, pp. 203-255.

SCHMÄHL, W. (1990c), Alterssicherung in der DDR und ihre Umgestaltung im Zuge des deutschen Einigungsprozesses / Old Age Security in the GDR and its Transformation in the Course of the German Unification; in German only / Centre for Social Policy Research, University of Bremen, Working paper No. 10/90, Bremen (forthcoming in G. Kleinhenz (Ed.), Sozialpolitik und deutsche Vereinigung, Berlin 1991.

SCHMÄHL, W. (1991), Transformation and Integration of Public Pension Schemes - Lessons from the Process of the German Unification, paper to be presented at the 47th Congress of the International Institute of Public Finance, Leningrad, mimeo.

SCHULZ, J. H. (1990), What Can Japan Teach Us About an Aging U.S. Work Force? in: Challenge, November-December, pp. 56-60.

STAEHLE, W. H. (1989), Employment of Older Persons from a Management Point of View. In: Schmähl (1989), pp. 163-173.

SUNDBERG, H. (1989), The Flexible Pensionable Age in Finland. In: Schmähl (1989), pp. 83-99.

THURMAN, J. and TRAH, G. (1990), Part-Time work in international perspective, in: Industrial Labour Review, pp. 23-40.

VERBRUGGE, L. M. (1984): Longer Life but worthening Health? Trends in Health and Mortality of middle-aged and older Persons, in: Milbank Memorial Fund Quarterly, Vol. 62, pp. 475-519. 